Article

\title{
Quantitative PCR Detection of Enteric Viruses in Wastewater and Environmental Water Sources by the Lisbon Municipality: A Case Study
}

\author{
Pedro Teixeira ${ }^{1,2,3, *}$, Sílvia Costa ${ }^{1}$, Bárbara Brown ${ }^{1}$, Susana Silva ${ }^{4} \oplus^{\circ}$, Raquel Rodrigues $^{3}$ and \\ Elisabete Valério ${ }^{3}$ \\ 1 Câmara Municipal de Lisboa, Direcção Municipal do Ambiente, Estrutura Verde, Clima e Energia, \\ Laboratório de Bromatologia e Águas, Avenida Cidade do Porto S/N-1700-111 Lisboa, Portugal; \\ silvia.a.costa@cm-lisboa.pt (S.C.); barbara.brown@cm-lisboa.pt (B.B.) \\ 2 Centro de Estudos do Ambiente e do Mar (CESAM), Faculdade de Ciências da Universidade de Lisboa, \\ Campo Grande, 1749-016 Lisboa, Portugal \\ 3 Departamento de Saúde Ambiental, Instituto Nacional de Saúde Doutor Ricardo Jorge, Avenida Padre Cruz, \\ 1649-016 Lisboa, Portugal; raquel.rodrigues@insa.min-saude.pt (R.R.); \\ elisabete.valerio@insa.min-saude.pt (E.V.) \\ 4 Departamento de Epidemiologia, Instituto Nacional de Saúde Doutor Ricardo Jorge, Avenida Padre Cruz, \\ 1649-016 Lisboa, Portugal; susana.pereira@insa.min-saude.pt \\ * Correspondence: pedro.teixeira@cm-lisboa.pt
}

Received: 10 January 2020; Accepted: 13 February 2020; Published: 15 February 2020

check for updates

\begin{abstract}
Current regulations and legislation require critical revision to determine safety for alternative water sources and water reuse as part of the solution to global water crisis. In order to fulfill those demands, Lisbon municipality decided to start water reuse as part of a sustainable hydric resources management, and there was a need to confirm safety and safeguard for public health for its use in this context. For this purpose, a study was designed that included a total of 88 samples collected from drinking, superficial, underground water, and wastewater at three different treatment stages. Quantitative Polimerase Chain Reaction (PCR) detection (qPCR) of enteric viruses Norovirus (NoV) genogroups I (GI) and II (GII) and Hepatitis A (HepA) was performed, and also FIB (E. coli, enterococci and fecal coliforms) concentrations were assessed. HepA virus was only detected in one untreated influent sample, whereas NoV GI/ NoV GI were detected in untreated wastewater (100/100\%), secondary treated effluent $(47 / 73 \%)$, and tertiary treated effluent $(33 / 20 \%)$. Our study proposes that NoV GI and GII should be further studied to provide the support that they may be suitable indicators for water quality monitoring targeting wastewater treatment efficiency, regardless of the level of treatment.
\end{abstract}

Keywords: norovirus; water reuse; water quality

\section{Introduction}

Monitoring every pathogenic microorganism potentially present in water, namely viruses, bacteria, protozoa, or fungi, is unrealistic given the number of resources necessary for that purpose. As an alternative, microbiological water quality assessment has been focused essentially on detecting fecal indicator bacteria (FIB), namely Escherichia coli (E. coli) and Enterococcus spp. [1-6]. FIB are used as surrogates for enteric pathogens in particular for monitoring fecal contamination in environmental waters, relying on the principle that FIB existence is concomitant with pathogen presence, as demonstrated in several studies $[7,8]$. However, there are also numerous studies showing that pathogens do not correlate significantly with FIB [9-18]. Since FIB, like E. coli and Enterococcus spp. 
are shed in most animal feces $[4,19,20]$, the lack of suitability between FIB levels and human health outcomes may be related to the FIB source. Amplifying the disconnection between FIB and pathogens is the ability for FIB not only to persist but to grow in environmental habitats like terrestrial soils, aquatic sediments, and aquatic vegetation [16,21-26]. Further studies are thus essential to assess the suitability of FIB as sole indicators not only in environmental waters but in an area that has been gaining more importance worldwide: treated wastewater use, as demand for water reuse, is increasing worldwide whether by necessity in developing countries or by environmental objectives in developed countries.

An efficient and sustainable hydric resources management allows non-potable uses for treated wastewater, such as irrigation, industrial processes, firefighting, recreational, or municipal services. Besides the existence of heavy metals, chemicals, hormones and endocrine disruptors in wastewater, it is still necessary to deal with the expected presence of resistant pathogenic microorganisms, many of which are not tested or included in current standards or legislation for water quality assessment. These microorganisms include viruses, bacteria, protozoa, and helminths, responsible for a significant number of potentially dangerous pathologies. There are some reports showing that wastewater treatment processes do not completely remove enteric viruses [27-29], even from effluents with adequate chlorine concentrations or UV treatment [30]. With an increase in reclaimed water use, the potential health impacts resultant from microbial contamination need to be further explored, as outbreaks of viral infectious diseases have been linked to insufficient treatment [31-33]. Several viruses, including Norovirus (NoV) and Hepatitis A (HepA), are listed in United States Environmental Protection Agency (USEPA's) drinking water Contaminant Candidate List (4-CCL 4), heightening waterborne viruses as a research priority [34]. According to a recent review by Teixeira et al. ([35], in press), numerous studies have focused on detecting enteric viruses in water samples, including treated and untreated wastewater, as well as environmental waters. Data on NoV and HepA viruses' concentrations, however, particularly in tertiary-treated wastewater, are scarce ([35], in press). Therefore, further studies are necessary to evaluate the adequate indicators for water reuse quality evaluation and support their application for regulatory purposes.

Globally, NoV is responsible for nearly $20 \%$ of all acute gastroenteritis cases [36], with 677 million cases per year and over 213,000 deaths [37]. In risk groups comprising children, elderly, or immunocompromised individuals, morbidity, and mortality rates of NoV infection are significant [38-42]. NoV exposure, and possible outbreaks, have been reported in schools, hospitals, cruise ships, nursing homes, swimming pools, and restaurants [43-47]. Transmission of the virus primarily occurs via fecal-oral contamination route, direct contact with an infected individual, and contaminated water or food consumption [47-51]. Contact with the virus may occur through drinking [52], recreational [44], or irrigation water [53], leading to waterborne outbreaks [54-56]. The vast contaminated aqueous sources linked to NoV indicate a ubiquitous distribution of the virus [57]. HepA virus transmission occurs mainly by the oral-fecal route (about 95\%), and ingestion of contaminated water and food [58-62]. HepA virus has been detected in drinking water, surface water, groundwater, treated, and untreated wastewater [63-67]. With global distribution, HepA is a major causal agent of acute viral hepatitis, with approximately 1.4 million cases reported annually globally [60,68], and a high endemicity of hepatitis A in regions with low sanitation [60,69,70].

Taking benefit from an existing standardized method for detecting NoV and HepA viruses in food and bottled water using real-time quantitative PCR detection (RT-qPCR) (ISO/TS, 15216-1:2017), the aim of our study was to develop a method based on this standardized method and assess the suitability of these enteric viruses as water quality indicators for water use and reuse. Moreover, the method developed aimed to be suitable for several water matrices-drinking, underground, superficial, treated, and untreated wastewater, thus enabling its use in routine water quality testing for detecting and quantifying NoV GI/GII and HepA viruses, and allowing managing entities to evaluate more accurately potential public health risks. 


\section{Materials and Methods}

\subsection{Sampling}

Fieldwork was carried out from February 2018 to December 2018, with a total of 88 samples collected. Sampling included: 1) underground water samples collected at two different sites in Lisbon $(\mathrm{n}=19)$; 2) superficial water intended for drinking water production $(\mathrm{n}=10)$; 3$)$ drinking water from Lisbon's supply system $(\mathrm{n}=11) ; 4)$ wastewater collected at a Wastewater Treatment Plant in the Lisbon district, at three different stages - untreated influent $(n=15)$, effluent with secondary treatment $(n=15)$ and effluent with tertiary, sand filtration and UV treatment $(n=15)$. Additionally, blank assays were performed with distilled, sterilized water samples $(n=3)$. All samples were collected in sterile polyethylene containers and stored at $4{ }^{\circ} \mathrm{C}$ for less than $2 \mathrm{~h}$ until chemical and microbiological determinations were initiated. $0.5 \mathrm{~mL}$ of a $10 \%$ dechlorination agent $\mathrm{Na}_{2} \mathrm{~S}_{2} \mathrm{O}_{3}$ was added to containers before sampling in order to neutralize possible existing residual chlorine from drinking water samples. Water samples for enteric viruses' determinations were collected in sterile glass containers. Enteric viruses were determined in different volumes according to the water source (25-5000 mL). Microbiological indicators were determined in $100 \mathrm{~mL}$, and chemical indicators were determined according to standard procedures, from a total of $1000 \mathrm{~mL}$ [71]. The time lapse between sample collection and laboratory processing did not exceed $24 \mathrm{~h}$.

\subsection{Detection and Quantification of Enteric Viruses}

The procedure established in this study was based on the international standard method for the determination of viruses in foods ISO/TS 15216-1:2017 [72]. Initially, $10 \mu \mathrm{L}$ of Mengo virus strain vMC0 (ceeramTOOLS ${ }^{\circledR}$, Biomérieux, France) were added to each sample, to be used as an internal process control to assure the RNA extraction efficiency. Samples with extraction efficiency, $\geq 1 \%$ were considered valid, as established in Norm ISO/TS 15216-1:2017 [72]. Viral particles were captured through filtration with a $0.45 \mu \mathrm{m}$ pore size $(47 \mathrm{~mm}$ diameter) positively charged nylon membrane (Amersham Hybond N+, GE Healthcare Life Sciences, UK), from $25 \mathrm{~mL}$ (untreated wastewater), $1000 \mathrm{~mL}$ (blank assay, secondary, tertiary treated wastewater and superficial water) and $5000 \mathrm{~mL}$ (drinking and underground water) samples. It should be noted that there are existing alternative protocols for virus collection [73], which stipulate significantly high volumes for filtration and virus collection in surface and groundwater-300 L and $1500 \mathrm{~L}$, respectively. For practical reasons, namely to avoid filter clogging and the possible inexistence of such water volumes in some groundwater sources, and more importantly, aiming to establishing a reasonably achievable method for detecting and quantification enteric viruses in diverse water samples for laboratories that perform the routine water monitoring, in this study different volumes were tested and filtered according to the sample matrix. Filters were then transferred into a sterile tube, and $4 \mathrm{~mL}$ of tris/glycine/beef extract (TGBE) buffer were added and shaken at approximately 50 oscillations $\min ^{-1}$ for $20 \pm 5 \mathrm{~min}$. An additional $4 \mathrm{~mL}$ of TGBE buffer was added, and the eluates pooled into a single clean tube. The $\mathrm{pH}$ was adjusted to $7.0 \pm 0.5$ with $\mathrm{HCl}(\geq 5 \mathrm{~mol} / \mathrm{L})$. Subsequently, samples were concentrated using Amicon ${ }^{\circledR}$ Ultra-15 Centrifugal Filter Devices with a 100 kDa molecular weight cut-off (Merck Millipore, Darmstadt, Germany), through centrifugation $4000 \mathrm{~g}$, at $4{ }^{\circ} \mathrm{C}$, for $15 \mathrm{~min}$. For RNA isolation, $500 \mu \mathrm{L} \mathrm{TRIzol}{ }^{\circledR}$ reagent (Thermo Fisher Scientific, Waltham, MA, USA) was added to the samples and mixed for 5 min, $30^{\circ} \mathrm{C}$ at $350 \mathrm{rpm}$ in a thermomixer (Eppendorf, Germany). Afterward, $200 \mu \mathrm{L}$ of chloroform were added and samples were mixed in a thermomixer (Eppendorf, Germany) for $3 \mathrm{~min}, 30^{\circ} \mathrm{C}$ at $350 \mathrm{rpm}$. Centrifugation was then performed for $15 \mathrm{~min}$, at $4^{\circ} \mathrm{C}$ and $12,000 \mathrm{~g}$. RNA was extracted from $140 \mu \mathrm{L}$ final volume (approx.) of the concentrated sample (aqueous phase) using a QIAamp Viral RNA Mini kit (QIAGEN, Hilden, Germany), according to the manufacturer's instructions. Samples were stored at $-80{ }^{\circ} \mathrm{C}$ until analysis. Quantitative Real-Time PCR (RT-qPCR) was performed (Applied Biosystems AB7500 qPCR) for the specific detection of NoV GI, NoV GII, and HepA viruses. An initial screening for the selected viruses was performed, in addition to confirmation for the absence of inhibitors with 
10-fold dilutions. RT-qPCR was performed for NoV GI, NoV GII, HepA, and Mengo virus detection and quantification, with the use of commercial kits (ceeramTOOLS ${ }^{\circledR}$, Biomérieux, France), according to the manufacturer's specifications.

\subsection{Microbiological Analysis}

Detection of total coliforms, E. coli, enterococci, and fecal coliforms was performed through the use of Colilert and Enterolert with Quanti-Tray (IDDEX Laboratories, Westbrook, ME, USA). Samples were processed according to manufacturer's instructions. For heterotrophic plate count at $22{ }^{\circ} \mathrm{C}$ and $37^{\circ} \mathrm{C}$, agar inclusion technique was performed using $1 \mathrm{~mL}$ aliquots of the water sample (after the necessary dilutions were performed) and adding $15 \mathrm{~mL}$ of Yeast Extract agar (VWR Chemicals, Radnor, PA, USA), and incubated at $36{ }^{\circ} \mathrm{C}$ for $44 \mathrm{~h}$ and $22{ }^{\circ} \mathrm{C}$ for $68 \mathrm{~h}$. After the incubation period at each temperature, all colonies were quantified for each case.

\subsection{Physical and Chemical Assessment}

Temperature and $\mathrm{pH}$ were both determined (Thermo Scientific ${ }^{\mathrm{TM}}$ Orion ${ }^{\mathrm{TM}} 3-$ Star Benchtop $\mathrm{pH}$ Meter, Thermo Fisher Scientific, Waltham, MA, USA) according to standard methods, as well as free chlorine and total organic carbon (TOC) [71]. Conductivity was measured according to Standard Guideline NP EN 27888:1996 (MeterLab CDM 210) and Mohr's Method was performed to assess chlorides.

\subsection{Statistical Analysis}

A descriptive analysis was made for numeric and categorical variables. For comparing different measures among the three wastewater treatment phases, a Kruskal-Wallis non-parametric or Fisher's Exact Test was used. When differences were found, multiple comparisons with Bonferroni correction was also performed. Correlation in each wastewater treatment phase was measured with the Pearson correlation coefficient. Statistical tests were performed bilaterally at a significance level of $5 \%$. The statistical analysis of the data was performed using statistical software R, version 3.4.3. [74].

\section{Results}

\subsection{Environmental and Drinking Waters}

A statistical summary for virus, microbiological, physical and chemical results (median) is presented in Table 1, concerning blank assays (BA), superficial water intended for drinking water production (DW1), drinking water from Lisbon's public supply system (DW2) and underground water samples collected at two different sites in Lisbon (GW1 and GW2). None of the enteric viruses targeted in this study-NoV GI, NoV GII, and HepA-were detected in samples from superficial water intended for drinking water production $(n=10)$, drinking water from Lisbon's supply system $(n=11)$ and underground water samples $(\mathrm{n}=19)$.

Microbiological, physical, and chemical results for drinking water samples $(\mathrm{n}=11)$ were all in compliance with national legislation-Law Decree No. 306/2007, 27th August, and Law Decree No. 236/1998, 1st August, with no microbial contamination detected. Environmental - superficial and underground bodies of water - presented similar and reduced levels of fecal contamination, with no significant differences between them (Table 1). Apart from conductivity and TOC, which presented lower and higher values, respectively, in the superficial water samples. The physical and chemical results were similar between the superficial and underground water samples. 
Table 1. Microbiological, physical, and chemical results (median) for blank assays (BA), superficial water intended for drinking water production (DW1), drinking water from Lisbon's supply system (DW2), and underground water samples collected at two different sites in Lisbon (GW1 and GW2). MNP-Most Probable Number, CFU—Colony Forming Units, GC-Genomic Copies. ND—Not detected. $\mathrm{n}=$ total analyzed samples. $\mathrm{LD}$ (limit of detection) $=1 \mathrm{MPN} / 100 \mathrm{~mL}$.

\begin{tabular}{|c|c|c|c|c|c|}
\hline & BA & DW1 & DW2 & GW1 & GW2 \\
\hline & $(n=3)$ & $(n=10)$ & $(\mathrm{n}=11)$ & $(n=8)$ & $(\mathrm{n}=11)$ \\
\hline Total Coliforms (MPN/100 mL) & $<\mathrm{LD}$ & $7.58 \times 10^{2}$ & $<\mathrm{LD}$ & $5.6 \times 10^{1}$ & $2.01 \times 10^{2}$ \\
\hline E. coli $(\mathrm{MPN} / 100 \mathrm{~mL})$ & $<\mathrm{LD}$ & 2 & $<\mathrm{LD}$ & 3 & $<\mathrm{LD}$ \\
\hline Fecal Coliforms (MPN/100 mL) & $<\mathrm{LD}$ & 1 & $<\mathrm{LD}$ & 2 & 1 \\
\hline Enterococcus (MPN/100 mL) & $<\mathrm{LD} 0$ & 4 & $<\mathrm{LD}$ & 5 & $2.6 \times 10^{1}$ \\
\hline $\mathrm{HPC} 37^{\circ} \mathrm{C}(\mathrm{CFU} / \mathrm{mL})$ & ND & $8.4 \times 10^{1}$ & ND & $1.4 \times 10^{1}$ & $1.57 \times 10^{2}$ \\
\hline $\mathrm{HPC} 22^{\circ} \mathrm{C}(\mathrm{CFU} / \mathrm{mL})$ & ND & $1.86 \times 10^{2}$ & ND & $8.9 \times 10^{1}$ & $3.01 \times 10^{2}$ \\
\hline TOC $(\mathrm{mg} / \mathrm{L})$ & 0.0 & 3.9 & 0.0 & 0.0 & 0.0 \\
\hline Chlorides $\left(\mathrm{mg} \mathrm{Cl}^{-} / \mathrm{L}\right)$ & 1 & 7 & 14 & 30 & 69 \\
\hline Free chlorine $\left(\mathrm{mg} \mathrm{Cl}_{2} / \mathrm{L}\right)$ & 0.06 & 0.06 & 0.60 & 0.08 & 0.07 \\
\hline Conductivity $\left(\mu \mathrm{S} / \mathrm{cm}\right.$ at $\left.20^{\circ} \mathrm{C}\right)$ & 2 & 71 & 173 & 552 & 827 \\
\hline $\mathrm{pH}\left(25^{\circ}\right)$ & 6.0 & 7.9 & 7.9 & 7.8 & 7.1 \\
\hline NoV GI (GC/100 mL) & ND & ND & ND & ND & ND \\
\hline NoV GII (GC/100 mL) & ND & ND & ND & ND & ND \\
\hline HepA (GC/100 mL) & ND & ND & ND & ND & ND \\
\hline
\end{tabular}

\subsection{Wastewater}

Untreated wastewater influent (WW1), effluent with secondary treatment (WW2) and effluent with tertiary treatment (WW3) statistical results summary for virus, microbiological, physical and chemical results (median) is presented in Table 2. HepA virus was only detected in one untreated influent sample, with a $3.99 \times 10^{6} \mathrm{gc} / 100 \mathrm{~mL}$ concentration. NoV GI was detected in all wastewater treatment stages - untreated wastewater influent $(n=15)$, effluent with secondary treatment $(n=7)$ and effluent with tertiary treatment $(n=5)$. Similar results were obtained for NoV GII with the following positive samples: untreated wastewater influent $(n=15)$, effluent with secondary treatment $(n=11)$ and effluent with tertiary treatment $(n=3)$. It can be noted that NoV GI median concentration reductions are significant between stages; a $6.67 \times 10^{7} \mathrm{gc} / 100 \mathrm{~mL}$ initial concentration is reduced to $8.34 \times 10^{6} \mathrm{gc} / 100 \mathrm{~mL}$ (WW2) and to $8.81 \times 10^{5} \mathrm{gc} / 100 \mathrm{~mL}$ final concentration. NoV GII initial $4.86 \times 10^{7} \mathrm{gc} / 100 \mathrm{~mL}$ median concentration is also significantly reduced with secondary treatment to $2.29 \times 10^{6} \mathrm{gc} / 100 \mathrm{~mL}$ (WW2). With UV and sand filtration, the effluent's concentration is also diminished $\left(9.69 \times 10^{5} \mathrm{gc} / 100 \mathrm{~mL}\right)$, although with no observed statistical significance.

Significant differences were found between all treatment wastewater phases for FIB and HPC at $37^{\circ} \mathrm{C}$ and $22{ }^{\circ} \mathrm{C}$ concentrations. Notably, we can observe a significant FIB decay not only with secondary treatment but also with tertiary sand filtration and UV treatment-after which FIB have been eliminated upon tertiary treatment (results $<$ limit of detection). According to current Portuguese national legislations-Law Decree No. 119/2019, 21st August-these effluents (with tertiary treatment) can be adequate for non-potable uses including irrigation, industrial uses, firefighting or street cleaning. Excluding chlorides, with no significant variations between wastewater treatments, the majority of the physical and chemical results, display a statistically significant reduction with secondary treatment activated sludge. 
Table 2. Microbiological, physical, and chemical results (median) for untreated wastewater influent (WW1), effluent with secondary treatment (WW2) and effluent with tertiary treatment (WW3). * Kruskall-Wallis non parametric test. ** Multiple comparisons tests with Bonferroni correction. a-Statistically significant difference between untreated influent and secondary treated effluent. $b-$ Statistically significant difference between untreated influent and tertiary treated effluent. c-Statistically significant difference between secondary and tertiary treated effluent. MNP-Most Probable Number, CFU—Colony Forming Units, GC-Genomic Copies. ND-Not Detected. $\mathrm{n}=$ total analyzed samples. LD (limit of detection) $=1 \mathrm{MPN} / 100 \mathrm{~mL}$.

\begin{tabular}{|c|c|c|c|c|c|}
\hline & WW1 & WW2 & WW3 & $P$-Value * & Pairwise Test** \\
\hline & $(\mathrm{n}=15)$ & $(\mathrm{n}=15)$ & $(\mathrm{n}=15)$ & & \\
\hline Total Coliforms (MPN/100 mL) & $7.70 \times 10^{7}$ & $9.80 \times 10^{4}$ & $<\mathrm{LD}$ & $<0.001$ & $a, b, c$ \\
\hline E. coli $(\mathrm{MPN} / 100 \mathrm{~mL})$ & $1.66 \times 10^{7}$ & $2.14 \times 10^{4}$ & $<\mathrm{LD}$ & $<0.001$ & $a, b, c$ \\
\hline Fecal Coliforms (MPN/100 mL) & $1.19 \times 10^{7}$ & $1.58 \times 10^{4}$ & $<\mathrm{LD}$ & $<0.001$ & $a, b, c$ \\
\hline Enterococcus (MPN/100 mL) & $3.99 \times 10^{6}$ & $8.80 \times 10^{3}$ & $<\mathrm{LD}$ & $<0.001$ & $a, b, c$ \\
\hline $\mathrm{HPC} 37^{\circ} \mathrm{C}(\mathrm{CFU} / \mathrm{mL})$ & $3.10 \times 10^{6}$ & $1.50 \times 10^{4}$ & 4 & $<0.001$ & $a, b, c$ \\
\hline $\mathrm{HPC} 22^{\circ} \mathrm{C}(\mathrm{CFU} / \mathrm{mL})$ & $4.20 \times 10^{6}$ & $2.04 \times 10^{4}$ & 2 & $<0.001$ & $a, b, c$ \\
\hline TOC (mg/L) & 169.0 & 7.90 & 7.70 & $<0.001$ & $\mathrm{a}, \mathrm{b}$ \\
\hline Chlorides $\left(\mathrm{mg} \mathrm{Cl}^{-} / \mathrm{L}\right)$ & 173 & 136 & 129 & 0.250 & - \\
\hline Free chlorine $\left(\mathrm{mg} \mathrm{Cl}_{2} / \mathrm{L}\right)$ & 0.06 & 0.10 & 0.09 & $<0.001$ & $\mathrm{a}, \mathrm{b}$ \\
\hline Conductivity $\left(\mu \mathrm{S} / \mathrm{cm}\right.$ at $\left.20^{\circ} \mathrm{C}\right)$ & 1262 & 839 & 860 & $<0.001$ & $\mathrm{a}, \mathrm{b}$ \\
\hline $\mathrm{pH}\left(25^{\circ}\right)$ & 8.0 & 7.0 & 7.5 & $<0.001$ & $a, b, c$ \\
\hline NoV GI (GC/100 mL) & $6.67 \times 10^{7}$ & $8.34 \times 10^{6}$ & $8.81 \times 10^{5}$ & $<0.001$ & $a, b, c$ \\
\hline NoV GII (GC/100 mL) & $4.86 \times 10^{7}$ & $2.29 \times 10^{6}$ & $9.69 \times 10^{5}$ & $<0.001$ & $\mathrm{a}, \mathrm{b}$ \\
\hline HepA (GC/100 mL) & $3.99 \times 10^{6}$ & ND & ND & - & - \\
\hline
\end{tabular}

Correlations between the microbiological parameters analyzed in each wastewater treatment phase (WW1, WW2 and WW3) were measured (Figure 1A-C). A positive correlation was observed between NoV GI and NoV GII in untreated influent $(\rho=0.54)$, and between NoV GI and fecal coliforms $(\rho=0.61)$. One of the highest correlations on this phase was found between Total Coliforms and Enterococcus $(\rho=0.68)$. Several positive correlations were detected for secondary treated effluent samples in microbiological parameters but none significant concerning NoV GI/GII. In tertiary treated effluents, only one moderate correlation was observed for $\operatorname{HPC} 22{ }^{\circ} \mathrm{C} / 37^{\circ} \mathrm{C}(\rho=0.60)$.

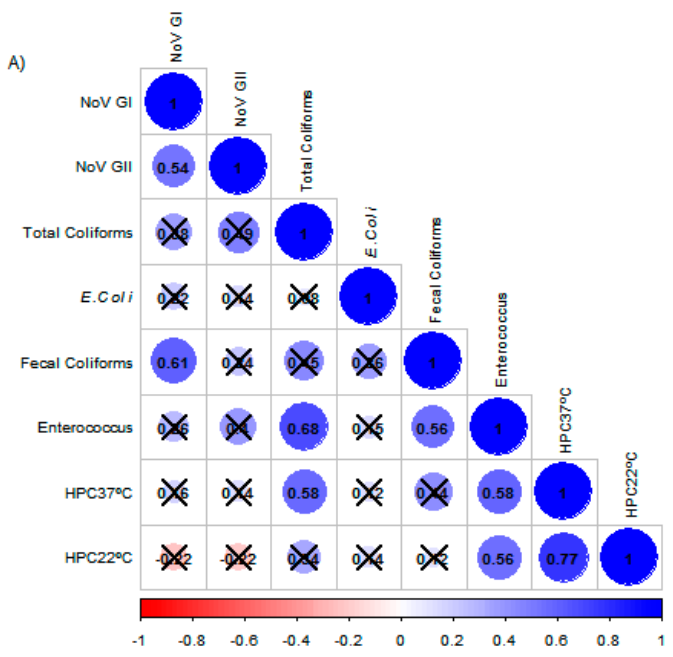

Figure 1. Cont. 

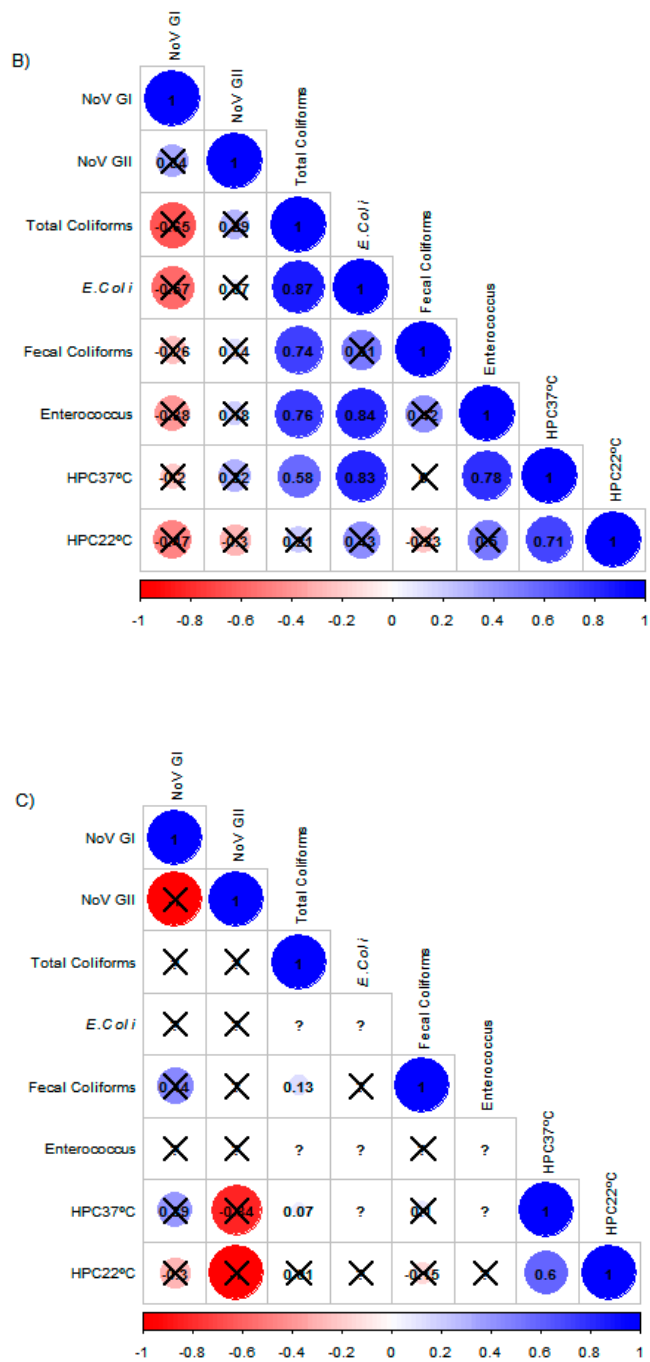

Figure 1. Graphical display of the correlation matrix of the microbiological parameters tested in each wastewater treatment phase (A) WW1, (B) WW2, and (C) WW3). The "?"-means "Not enough finite observations".

\section{Discussion and Conclusions}

In the case of environmental and drinking waters, enteric viruses NoV GI, NoV GII, and HepA virus were not detected in any of the samples in drinking, superficial, or underground water, suggesting an absence of fecal contamination from a human source in these types of water. However, the presence of total coliforms, E. coli, enterococci, and fecal coliforms were detected in samples from underground and superficial samples, and though in reduced concentrations, it suggests a natural and expected fecal contamination from animal origin. Studies showed that $\mathrm{NoV}$, could be detected in particularly high concentrations in feces - up to $10^{11} \mathrm{GC} / \mathrm{g}$ [75]. Consequently, the occurrence of NoV in surface waters can be linked to contaminated water sources (i.e., fecal contamination) and with environmental conditions determining the survival of the virus [14,76]. Since these viruses are highly infectious [49] and demonstrate a high resistance to environmental degradation in water [77-79], its presence in surface and groundwater intended for human consumption raises as a potential public health risk, by which frequent monitoring of enteric viruses such as NoV besides FIB, could be desirable and prudent.

On what concerns the treated wastewaters, our results demonstrate that the absence of FIB does not imply the absence of pathogenic microorganisms, namely NoV GI and GII in tertiary treated wastewater (obtained after sand filtration and UV). FIB monitoring and their correlations with enteric 
viruses have recently been questioned [17,80,81], hence the necessity for more adequate indicators in water quality monitoring, especially for wastewater use. Growing water resources management concerns arise, not only in areas affected by droughts but also importantly in urban areas, like the one targeted in this study-Lisbon, where water reuse represents one of the municipality's commitments as part of a sustainable hydric resources management, with self-evident safeguard for public health. The results here obtained for Nov GI and GII concentrations are in accordance with previous studies targeting untreated, secondary, and tertiary treated wastewater [82-85].

The results of our study support the hypothesis that NoV GI and GII might be suitable indicators for water quality monitoring regarding wastewater treatment efficiency, regardless of the level of the treatment-secondary or tertiary. A correlation between NoV (GI) and FIB (fecal coliforms) is observed in untreated effluent, but in subsequent treatment phases, there was no correlation between the targeted enteric viruses and FIB. While positive correlations observed between FIB and NoV in untreated wastewater could be expected and were indeed observed, the absence of correlations between FIB and secondary and tertiary treatment stages points out to a lack of a link between FIB and the targeted enteric viruses concentrations. Moreover, in several samples with an apparent total FIB elimination with UV and sand filtration treatment, NoV was still detectable. Our results point out to the need of further studies and expansion to different WWTPs, in diverse locations and including a higher number of samples, not only to further reinforce the results of this study and validate our hypothesis but also to expand detection methods to other viral pathogens and evaluate the best and most comprehensive indicators to use for water reuse situations. While cell culture methods have been the gold standard for the detection of infectious viruses, qPCR methods became essential for enteric virus detection in water samples due to shorter detection times, high sensitivity and specificity, and the ability to detect viruses that are not easily or at all culturable [86]. A significant limitation of the method applied in our study is the inability to differentiate infective viruses from non-infective viruses. Nonetheless, viral genomes are present in water samples, particularly in reclaimed wastewater. Considering an estimated 50\% infectious dose (ID50) between 18 and 1,015 genomic equivalents [49], public health risks may arise even from non-potable uses like irrigation or street cleaning, as incorrect usage of treated wastewater has caused outbreaks of viral infectious diseases worldwide [31-33]. To this fact, it must enhance while qPCR delivers quantitative data with high accuracy; results obtained by this method should be interpreted prudently because of potential losses during the sample concentration/extraction/purification procedure, which may result in an underestimation in the detection/quantification process [86]. The whole process control used in our study - Mengo virus allowed evaluating the efficiency for virus recovery in the different stages - from sample concentration and RNA extraction, to RT-qPCR. However, even within the established ISO values (recovery $\geq 1 \%$ ), the obtained recovery rates for this control were usually low $(<10 \%)$, which can underestimate NoV GI and GII concentrations, particularly in reclaimed wastewater. Importantly, this study shows that a procedure based on the international standard method for the determination of viruses in foods ISO/TS 15216-1 [72] could be applied for routine water quality monitoring of NoV and HepA, in different water matrices.

The importance of FIB is undoubtedly as they are responsible for a significant improvement in water quality assessment and safety management for many decades [1]. Nevertheless, current regulations and legislation require critical revision to determine safety in particular for water reuse, as we can observe samples determined compliant for bacterial indicators that are positive for NoV GI and GII presence. Representing a key to the global water crisis, water reuse should also be determined safe considering the different treatments applied, as enteric viruses' infections also represent a worldwide economic concern.

Author Contributions: Conceptualization, E.V. and P.T.; methodology, E.V. and P.T.; validation, E.V. and P.T; formal analysis, P.T., E.V. and S.S.; investigation, P.T., S.C., B.B. and E.V.; resources, P.T., R.R. and E.V.; data curation, P.T. and E.V.; writing-original draft preparation, P.T.; writing-review and editing, E.V., P.T., S.C., S.S., B.B and R.R.; visualization, P.T., S.S. and E.V.; supervision, E.V.; project administration, E.V. and P.T.; funding acquisition, P.T. and E.V. All authors have read and agreed to the published version of the manuscript. 
Funding: This research was funded by the Lisbon Municipality (CML) in collaboration with Instituto Nacional de Saúde Doutor Ricardo Jorge (INSA).

Acknowledgments: The authors are grateful to Ângelo Mesquita and José Canêdo for their contributions to the implementation of this project. We would also like to thank Helena Rebelo and João Brandão for all the help provided. Any opinions, findings and conclusions expressed are those of the authors and do not necessarily reflect the views of the Lisbon Municipality.

Conflicts of Interest: The authors declare no conflict of interest.

\section{References}

1. Tallon, P.; Magajna, B.; Lofranco, C.; Leung, K.T. Microbial Indicators of Faecal Contamination in Water: A Current Perspective. Water. Air. Soil Pollut. 2005, 166, 139-166. [CrossRef]

2. José Figueras, M.; Borrego, J.J. New perspectives in monitoring drinking water microbial quality. Int. J. Environ. Res. Public Health 2010, 7, 4179-4202. [CrossRef] [PubMed]

3. Saxena, G.; Bharagava, R.N.; Kaithwas, G.; Raj, A. Microbial indicators, pathogens and methods for their monitoring in water environment. J. Water Health 2015, 13, 319-339. [CrossRef] [PubMed]

4. Leclerc, H.; Mossel, D.A.A.; Edberg, S.C.; Struijk, C.B. Advances in the Bacteriology of the Coliform Group: Their Suitability as Markers of Microbial Water Safety. Annu. Rev. Microbiol. 2001, 55, 201-234. [CrossRef]

5. WHO. Guidelines for safe recreational water environments-Coastal and Fresh waters. Guidel. Safe Recreat. Water. 2003, 1, 253.

6. EPA. Recreational Water Quality Criteria. Available online: https://www.epa.gov/sites/production/files/201510/documents/rwqc2012.pdf (accessed on 13 February 2020).

7. Wade, T.J.; Sams, E.; Brenner, K.P.; Haugland, R.; Chern, E.; Beach, M.; Wymer, L.; Rankin, C.C.; Love, D.; Li, Q.; et al. Rapidly measured indicators of recreational water quality and swimming-associated illness at marine beaches: A prospective cohort study. Environ. Heal. A Glob. Access Sci. Source 2010, 9, 1-14. [CrossRef]

8. Zmirou, D.; Pena, L.; Ledrans, M.; Letertre, A. Risks associated with the microbiological quality of bodies of fresh and marine water used for recreational purposes: Summary estimates based on published epidemiological studies. Arch. Environ. Health 2003, 58, 703-711. [CrossRef]

9. Lund, V. Evaluation of E. Coli as an indicator for the presence of Campylobacter jejuni and Yersinia enterocolitica in chlorinated and untreated oligotrophic lake water. Water Res. 1996, 30, 1528-1534. [CrossRef]

10. Bonadonna, L.; Briancesco, R.; Ottaviani, M.; Veschetti, E. Occurrence of Cryptosporidium oocysts in sewage effluents and correlation with microbial, chemical and physical water variables. Environ. Monit. Assess. 2002, 75, 241-252. [CrossRef]

11. Lemarchand, K.; Lebaron, P. Occurrence of Salmonella spp. and Cryptosporidium spp. in a French coastal watershed: Relationship with fecal indicators. FEMS Microbiol. Lett. 2003, 218, 203-209. [CrossRef]

12. Harwood, V.J.; Levine, A.D.; Scott, T.M.; Chivukula, V.; Lukasik, J.; Farrah, S.R.; Rose, J.B. Validity of the indicator organism paradigm for pathogen reduction in reclaimed water and public health protection. Appl. Environ. Microbiol. 2005, 71, 3163-3170. [CrossRef]

13. Anderson, K.L.; Whitlock, J.E.; Valerie, J.; Harwood, V.J. Persistence and Differential Survival of Fecal Indicator Bacteria in Subtropical Waters and Sediments. Appl. Environ. Microbiol. 2005, 71, 3041-3048. [CrossRef]

14. Hörman, A.; Rimhanen-finne, R.; Maunula, L.; Von Bonsdorff, C.; Torvela, N. Indicator Organisms in Surface Water in and Indicator Organisms in Surface Water in Southwestern Finland, 2000-2001. Appl. Environ. Microbiol. 2004, 70, 87-95. [CrossRef]

15. Zhang, Q.; Eichmiller, J.J.; Staley, C.; Sadowsky, M.J.; Ishii, S. Correlations between pathogen concentration and fecal indicator marker genes in beach environments. Sci. Total Environ. 2016, 15, 826-830. [CrossRef]

16. Bradshaw, J.K.; Snyder, B.J.; Oladeinde, A.; Spidle, D.; Berrang, M.E.; Meinersmann, R.J.; Oakley, B.; Sidle, R.C.; Sullivan, K.; Molina, M. Characterizing relationships among fecal indicator bacteria, microbial source tracking markers, and associated waterborne pathogen occurrence in stream water and sediments in a mixed land use watershed. Water Res. 2016, 101, 498-509. [CrossRef] 
17. McQuaig, S.; Griffith, J.; Harwood, V.J. Association of fecal indicator bacteria with human viruses and microbial source tracking markers at coastal beaches impacted by nonpoint source pollution. Appl. Environ. Microbiol. 2012, 78, 6423-6432. [CrossRef]

18. Arnold, B.F.; Schiff, K.C.; Griffith, J.F.; Gruber, J.S.; Yau, V.; Wright, C.C.; Wade, T.J.; Burns, S.; Hayes, J.M.; Mcgee, C.; et al. Swimmer illness associated with marine water exposure and water quality indicators: Impact of widely used assumptions. Epidemiology 2013, 24, 845-853. [CrossRef]

19. Harwood, V.J.; Butler, J.; Parrish, D.; Wagner, V. Isolation of fecal coliform bacteria from the diamondback terrapin (Malaclemys terrapin centrata). Appl. Environ. Microbiol. 1999, 65, 865-867. [CrossRef]

20. Field, K.G.; Samadpour, M. Fecal source tracking, the indicator paradigm, and managing water quality. Water Res. 2007, 41, 3517-3538. [CrossRef]

21. Solo-Gabriele, H.M.; Wolfert, M.A.; Desmarais, T.R.; Palmer, C.J. Sources of Escherichia coli in a coastal subtropical environment. Appl. Environ. Microbiol. 2000, 66, 230-237. [CrossRef]

22. Byappanahalli, M.N.; Shively, D.A.; Nevers, M.B.; Sadowsky, M.J.; Whitman, R.L. Growth and survival of Escherichia coli and enterococci populations in the macro-alga Cladophora (Chlorophyta). FEMS Microbiol. Ecol. 2003, 46, 203-211. [CrossRef]

23. Jeng, H.C.; England, A.J.; Bradford, H.B. Indicator organisms associated with stormwater suspended particles and estuarine sediment. J. Environ. Sci. Heal. Part A Toxic/Hazardous Subst. Environ. Eng. 2005, 40, 779-791. [CrossRef] [PubMed]

24. Badgley, B.D.; Thomas, F.I.M.; Harwood, V.J. Quantifying environmental reservoirs of fecal indicator bacteria associated with sediment and submerged aquatic vegetation. Environ. Microbiol. 2011, 13, 932-942. [CrossRef] [PubMed]

25. Eifan, S.A. Enteric Viruses And Aquatic Environment. Internet J. Microbiol. 2013, 12, 1-7.

26. He, X.; Wei, Y.; Cheng, L.; Zhang, D.; Wang, Z. Molecular detection of three gastroenteritis viruses in urban surface waters in Beijing and correlation with levels of fecal indicator bacteria. Environ. Monit. Assess. 2012, 184, 5563-5570. [CrossRef]

27. Blatchley, E.R.; Gong, W.-L.; Alleman, J.E.; Rose, J.B.; Huffman, D.E.; Otaki, M.; Lisle, J.T. Effects of Wastewater Disinfection on Waterborne Bacteria and Viruses. Water Environ. Res. 2007, 79, 81-92. [CrossRef]

28. El-Senousy, W.M.; Guix, S.; Abid, I.; Pintó, R.M.; Bosch, A. Removal of astrovirus from water and sewage treatment plants, evaluated by a competitive reverse transcription-PCR. Appl. Environ. Microbiol. 2007, 73, 164-167. [CrossRef]

29. Lazarova, V.; Levine, B.; Sack, J.; Cirelli, G.; Jeffrey, P.; Muntau, H.; Salgot, M.; Brissaud, F. Role of water reuse for enhancing integrated water management in Europe and Mediterranean countries. Water Sci. Technol. 2001, 43, 25-33. [CrossRef]

30. Sano, D.; Amarasiri, M.; Hata, A.; Watanabe, T.; Katayama, H. Risk management of viral infectious diseases in wastewater reclamation and reuse: Review. Environ. Int. 2016, 91, 220-229. [CrossRef]

31. Bernard, H.; Faber, M.; Wilking, H.; Haller, S.; Höhle, M.; Schielke, A.; Ducomble, T.; Siffczyk, C.; Merbecks, S.; Fricke, G.; et al. Large multistate outbreak of norovirus gastroenteritis associated with frozen strawberries, Germany, 2012. Eurosurveillance 2014, 19, 20719. [CrossRef]

32. Okoh, A.I.; Sibanda, T.; Gusha, S.S. Inadequately treated wastewater as a source of human enteric viruses in the environment. Int. J. Environ. Res. Public Health 2010, 7, 2620-2637. [CrossRef] [PubMed]

33. Sinclair, R.G.; Jones, E.L.; Gerba, C.P. Viruses in recreational water-borne disease outbreaks: A review. J. Appl. Microbiol. 2009, 107, 1769-1780. [CrossRef] [PubMed]

34. United States Environmental Protection Agency. Contaminant Candidate List (CCL) and Regulatory Determination. Available online: https://www.epa.gov/ccl/microbial-contaminants-ccl-4 (accessed on 30 January 2020).

35. Teixeira, P.; Salvador, D.; Brandão, J.; Ahmed, W.; Sadowsky, M.J.; Valério, E. Environmental and Adaptive Changes Necessitate a Paradigm Shift for Indicators of Fecal Contamination. Microbiol Spectr.. in press.

36. Ahmed, S.M.; Hall, A.J.; Robinson, A.E.; Verhoef, L.; Premkumar, P.; Parashar, U.D.; Koopmans, M.; Lopman, B.A. Global prevalence of norovirus in cases of gastroenteritis: A systematic review and meta-analysis. Lancet Infect. Dis. 2014, 14, 725-730. [CrossRef]

37. Pires, S.M.; Fischer-Walker, C.L.; Lanata, C.F.; Devleesschauwer, B.; Hall, A.J.; Kirk, M.D.; Duarte, A.S.R.; Black, R.E.; Angulo, F.J. Aetiology-specific estimates of the global and regional incidence and mortality of diarrhoeal diseases commonly transmitted through food. PLoS ONE 2015, 10, e0142927. [CrossRef] 
38. Harris, J.P.; Edmunds, W.J.; Pebody, R.; Brown, D.W.; Lopman, B.A. Deaths from norovirus among the elderly, England and Wales. Emerg. Infect. Dis. 2008, 14, 1546-1552. [CrossRef]

39. Hutson, A.M.; Atmar, R.L.; Estes, M.K. Norovirus disease: Changing epidemiology and host susceptibility factors. Trends Microbiol. 2004, 12, 279-287. [CrossRef]

40. Payne, D.C.; Vinjé, J.; Szilagyi, P.G.; Edwards, K.M.; Staat, M.A.; Weinberg, G.A.; Hall, C.B.; Chappell, J.; Bernstein, D.I.; Curns, A.T.; et al. Norovirus and medically attended gastroenteritis in U.S. children. N. Engl. J. Med. 2013, 368, 1121-1130. [CrossRef]

41. Siebenga, J.J.; Vennema, H.; Zheng, D.; Vinjé, J.; Lee, B.E.; Pang, X.; Ho, E.C.M.; Lim, W.; Choudekar, A.; Broor, S.; et al. Norovirus Illness Is a Global Problem: Emergence and Spread of Norovirus GII.4 Variants, 2001-2007. J. Infect. Dis. 2009, 200, 802-812. [CrossRef]

42. Tian, G.; Jin, M.; Li, H.; Li, Q.; Wang, J.; Duan, Z.J. Clinical characteristics and genetic diversity of noroviruses in adults with acute gastroenteritis in Beijing, China in 2008-2009. J. Med. Virol. 2014, 86, 1235-1242. [CrossRef]

43. Fankhauser, R.L.; Monroe, S.S.; Noel, J.S.; Humphrey, C.D.; Bresee, J.S.; Parashar, U.D.; Ando, T.; Glass, R.I. Epidemiologic and Molecular Trends of "Norwalk-like Viruses" Associated with Outbreaks of Gastroenteritis in the United States. J. Infect. Dis. 2002, 186, 1-7. [CrossRef] [PubMed]

44. Podewils, L.J.; Zanardi Blevins, L.; Hagenbuch, M.; Itani, D.; Burns, A.; Otto, C.; Blanton, L.; Adams, S.; Monroe, S.S.; Beach, M.J.; et al. Outbreak of norovirus illness associated with a swimming pool. Epidemiol. Infect. 2007, 135, 827-833. [CrossRef] [PubMed]

45. White, P.A. Evolution of norovirus. Clin. Microbiol. Infect. 2014, 20, 741-745. [CrossRef] [PubMed]

46. Xerry, J.; Gallimore, C.I.; Iturriza-Gómara, M.; Allen, D.J.; Gray, J.J. Transmission events within outbreaks of gastroenteritis determined through analysis of nucleotide sequences of the P2 domain of genogroup II noroviruses. J. Clin. Microbiol. 2008, 46, 947-953. [CrossRef] [PubMed]

47. Widdowson, M.A.; Sulka, A.; Bulens, S.N.; Beard, R.S.; Chaves, S.S.; Hammond, R.; Salehi, E.D.P.; Swanson, E.; Totaro, J.; Woron, R.; et al. Norovirus and foodborne disease, United States, 1991-2000. Emerg. Infect. Dis. 2005, 11, 95-102. [CrossRef]

48. Kotwal, G.; Cannon, J.L. Environmental persistence and transfer of enteric viruses. Curr. Opin. Virol. 2014, 4, 37-43. [CrossRef]

49. Teunis, P.F.M.; Moe, C.L.; Liu, P.; Miller, S.E.; Lindesmith, L.; Baric, R.S.; Le Pendu, J.; Calderon, R.L. Norwalk virus: How infectious is it? J. Med. Virol. 2008, 80, 1468-1476. [CrossRef]

50. Bitler, E.J.; Matthews, J.E.; Dickey, B.W.; Eisenberg, J.N.S.; Leon, J.S. Norovirus outbreaks: A systematic review of commonly implicated transmission routes and vehicles. Epidemiol. Infect. 2013, 141, 1563-1571. [CrossRef]

51. Glass, R.I.; Parashar, U.D.; Estes, M.K. Current Concepts-Norovirus Gastroenteritis. N. Engl. J. Med. 2009, 361, 1776-1785. [CrossRef]

52. Kukkula, M.; Maunula, L.; Silvennoinen, E.; Von Bonsdorff, C. Outbreak of Viral Gastroenteritis Due to Drinking Water Contaminated by Norwalk-like Viruses. J. Infect. Dis. 1999, 180, 1771-1776. [CrossRef]

53. Doyle, M.P.; Erickson, M.C. Summer meeting 2007-The problems with fresh produce: An overview. J. Appl. Microbiol. 2008, 105, 317-330. [CrossRef] [PubMed]

54. Maunula, L.; Miettinen, I.T.; Von Bonsdorff, C.H. Norovirus outbreaks from drinking water. Emerg. Infect. Dis. 2005, 11, 1716-1721. [CrossRef] [PubMed]

55. Riera-Montes, M.; Brus Sjölander, K.; Allestam, G.; Hallin, E.; Hedlund, K.O.; Löfdahl, M. Waterborne norovirus outbreak in a municipal drinking-water supply in Sweden. Epidemiol. Infect. 2011, 139, 1928-1935. [CrossRef] [PubMed]

56. Matthews, J.E.; Dickey, B.W.; Miller, R.D.; Felzer, J.R.; Dawson, B.P.; Lee, A.S.; Rocks, J.J.; Kiel, J.; Montes, J.S.; Moe, C.L.; et al. The epidemiology of published norovirus outbreaks: A review of risk factors associated with attack rate and genogroup. Epidemiol. Infect. 2012, 140, 1161-1172. [CrossRef]

57. Robilotti, E.; Deresinski, S.; Pinsky, B.A. Norovirus. Clin. Microbiol. Rev. 2015, 28, 134-164. [CrossRef]

58. Yezli, S.; Otter, J.A. Minimum Infective Dose of the Major Human Respiratory and Enteric Viruses Transmitted Through Food and the Environment. Food Environ. Virol. 2011, 3, 1-30. [CrossRef]

59. Ciocca, M. Clinical course and consequences of hepatitis A infection. Vaccine 2000, 18, S71-S74. [CrossRef]

60. Yong, H.T.; Son, R. Review Article Hepatitis A virus-A general overview. Int. Food Res. J. 2009, 467, 455-467. 
61. Jacobsen, K.H.; Wiersma, S.T. Hepatitis A virus seroprevalence by age and world region, 1990 and 2005. Vaccine 2010, 28, 6653-6657. [CrossRef]

62. Yeh, H.Y.; Hwang, Y.C.; Yates, M.V.; Mulchandani, A.; Chen, W. Detection of hepatitis A virus by using a combined cell culture-molecular beacon assay. Appl. Environ. Microbiol. 2008, 74, 2239-2243. [CrossRef]

63. Borchardt, M.A.; Spencer, S.K.; Kieke, B.A.; Lambertini, E.; Loge, F.J. Viruses in nondisinfected drinking water from municipal wells and community incidence of acute gastrointestinal illness. Environ. Health Perspect. 2012, 120, 1272-1279. [CrossRef] [PubMed]

64. Hellmér, M.; Paxéus, N.; Magnius, L.; Enache, L.; Arnholm, B.; Johansson, A.; Bergström, T.; Norder, H. Detection of pathogenic viruses in sewage provided early warnings of hepatitis A virus and norovirus outbreaks. Appl. Environ. Microbiol. 2014, 80, 6771-6781. [CrossRef] [PubMed]

65. Ouardani, I.; Manso, C.F.; Aouni, M.; Romalde, J.L. Efficiency of hepatitis A virus removal in six sewage treatment plants from central Tunisia. Appl. Microbiol. Biotechnol. 2015, 99, 10759-10769. [CrossRef] [PubMed]

66. Chigor, V.N.; Sibanda, T.; Okoh, A.I. Assessment of the Risks for Human Health of Adenoviruses, Hepatitis A Virus, Rotaviruses and Enteroviruses in the Buffalo River and Three Source Water Dams in the Eastern Cape. Food Environ. Virol. 2014, 6, 87-98. [CrossRef] [PubMed]

67. Dias, J.; Pinto, R.N.; Vieira, C.B.; de Abreu Corrêa, A. Detection and quantification of human adenovirus (HAdV), JC polyomavirus (JCPyV) and hepatitis A virus (HAV) in recreational waters of Niterói, Rio de Janeiro, Brazil. Mar. Pollut. Bull. 2018, 133, 240-245. [CrossRef] [PubMed]

68. Jacobsen, K.H. The Global Prevalence of Hepatitis A Virus Infection and Susceptibility: A Systematic Review (No. WHO/IVB/10.01); WHO Press: Geneva, Switzerland, 2009.

69. Gupta, E.; Ballani, N. State of the globe: Hepatitis A virus-Return of a water devil. J. Glob. Infect. Dis. 2014, 6, 57-58. [CrossRef]

70. Osuolale, O.; Okoh, A. Incidence of human adenoviruses and Hepatitis A virus in the final effluent of selected wastewater treatment plants in Eastern Cape Province, South Africa. Virol. J. 2015, 12, 1-8. [CrossRef]

71. APHA/AWWA/WEF. Standard Methods for the Examination of Water and Wastewater. 2012. Available online: https://beta-static.fishersci.com/content/dam/fishersci/en_US/documents/programs/scientific/ technical-documents/white-papers/apha-water-testing-standard-methods-white-paper.pdf (accessed on 13 February 2020).

72. ISO. Microbiology of the Food Chain-Horizontal Method for Determination of Hepatitis A Virus and Norovirus Using Real-Time RT-PCR_Part 1: Method for Quantification. ISO/TS 15216-1. Available online: https://www.iso.org/standard/65681.html (accessed on 13 February 2020).

73. Fout, G.S.; Cashdollar, J.L.; Varughese, E.A.; Parshionikar, S.U.; Grimm, A.C. EPA method 1615. Measurement of enterovirus and norovirus occurrence in water by culture and RT-qPCR. I. collection of virus samples. J. Vis. Exp. 2015, e52067. [CrossRef]

74. R Core Team. R: A Language and Environment for Statistical Computing. Available online: https: //www.r-project.org/ (accessed on 16 July 2019).

75. Atmar, R.L.; Opekun, A.R.; Gilger, M.A.; Estes, M.K.; Crawford, S.E.; Neill, F.H.; Graham, D.Y. Norwalk virus shedding after experimental human infection. Emerg. Infect. Dis. 2008, 14, 1553-1557. [CrossRef]

76. Lee, S.G.; Jheong, W.H.; Suh, C.I.; Kim, S.H.; Lee, J.B.; Jeong, Y.S.; Ko, G.P.; Jang, K.L.; Lee, G.C.; Paik, S.Y. Nationwide groundwater surveillance of noroviruses in South Korea, 2008. Appl. Environ. Microbiol. 2011, 77, 1466-1474. [CrossRef] [PubMed]

77. Bae, J.; Schwab, K.J. Evaluation of murine norovirus, feline calicivirus, poliovirus, and MS2 as surrogates for human norovirus in a model of viral persistence in surface water and groundwater. Appl. Environ. Microbiol. 2008, 74, 477-484. [CrossRef] [PubMed]

78. Ngazoa, E.S.; Fliss, I.; Jean, J. Quantitative study of persistence of human norovirus genome in water using TaqMan real-time RT-PCR. J. Appl. Microbiol. 2008, 104, 707-715. [CrossRef] [PubMed]

79. Seitz, S.R.; Leon, J.S.; Schwab, K.J.; Lyon, G.M.; Dowd, M.; McDaniels, M.; Abdulhafid, G.; Fernandez, M.L.; Lindesmith, L.C.; Baric, R.S.; et al. Norovirus infectivity in humans and persistence in water. Appl. Environ. Microbiol. 2011, 77, 6884-6888. [CrossRef]

80. Wyer, M.D.; Wyn-Jones, A.P.; Kay, D.; Au-Yeung, H.K.C.; Gironés, R.; López-Pila, J.; de Roda Husman, A.M.; Rutjes, S.; Schneider, O. Relationships between human adenoviruses and faecal indicator organisms in European recreational waters. Water Res. 2012, 46, 4130-4141. [CrossRef] 
81. Henry, R.; Schang, C.; Kolotelo, P.; Coleman, R.; Rooney, G.; Schmidt, J.; Deletic, A.; McCarthy, D.T. Effect of environmental parameters on pathogen and faecal indicator organism concentrations within an urban estuary. Estuar. Coast. Shelf Sci. 2016, 174, 18-26. [CrossRef]

82. Da Silva, A.K.; Le Saux, J.C.; Parnaudeau, S.; Pommepuy, M.; Elimelech, M.; Le Guyader, F.S. Evaluation of removal of noroviruses during wastewater treatment, using real-time reverse transcription-PCR: Different behaviors of genogroups I and II. Appl. Environ. Microbiol. 2007, 73, 7891-7897. [CrossRef]

83. Iwai, M.; Hasegawa, S.; Obara, M.; Nakamura, K.; Horimoto, E.; Takizawa, T.; Kurata, T.; Sogen, S.I.; Shiraki, K. Continuous presence of noroviruses and sapoviruses in raw sewage reflects infections among inhabitants of Toyama, Japan (2006 to 2008). Appl. Environ. Microbiol. 2009, 75, 1264-1270. [CrossRef]

84. López-Gálvez, F.; Truchado, P.; Sánchez, G.; Aznar, R.; Gil, M.I.; Allende, A. Occurrence of enteric viruses in reclaimed and surface irrigation water: Relationship with microbiological and physicochemical indicators. J. Appl. Microbiol. 2016, 121, 1180-1188. [CrossRef]

85. Haramoto, E.; Fujino, S.; Otagiri, M. Distinct behaviors of infectious F-specific RNA coliphage genogroups at a wastewater treatment plant. Sci. Total Environ. 2015, 520, 32-38. [CrossRef]

86. Haramoto, E.; Kitajima, M.; Hata, A.; Torrey, J.R.; Masago, Y.; Sano, D.; Katayama, H. A review on recent progress in the detection methods and prevalence of human enteric viruses in water. Water Res. 2018, 135, 168-186. [CrossRef] [PubMed]

(C) 2020 by the authors. Licensee MDPI, Basel, Switzerland. This article is an open access article distributed under the terms and conditions of the Creative Commons Attribution (CC BY) license (http://creativecommons.org/licenses/by/4.0/). 